Historic, Archive Document

Do not assume content reflects current scientific knowledge, policies, or practices. 



\section{The World's Finest Irises}

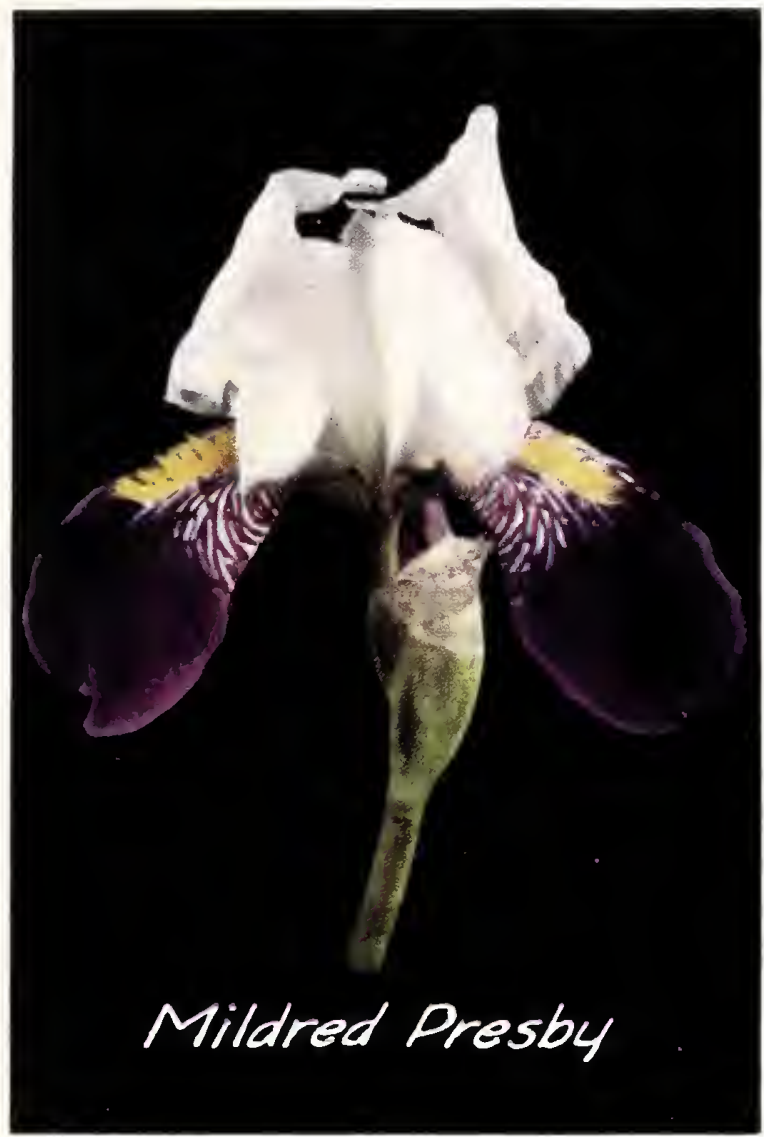

\section{RATINGS}

The figures given immediately following the name of a variety are the official ratings of the American Iris Society, the first figure being the "Exhibition Rating," the second figure the "Garden Rating." Those not rated are rare or recently introduced varieties that were not sufficiently well known to the jurors to rate them. In the American Iris Society rating, 100 is considered perfect, but no Iris is ever voted 100 , because room must always be left for improvement. The official ratings are as follows:

$$
\begin{array}{ll}
95, \text { almost perfect } & 70, \text { good } \\
90, \text { very fine } & 60, \text { good but no } \\
85, \text { fine } & 50, \text { fair } \\
80, \text { very good } & \text { Below } 50, \text { poor }
\end{array}
$$

The heights given are the heights of flowering stalk in my gardens. The name and date in parenthesis is the name of the originator and the year introduced.

The upper petals of the flower that usually stand up straight are called "Standards"; the lower petals that fall down are called "Falls."

All plants are guaranteed true to name, and there is no place in the world where they grow better than right here in Bayside. I guarantee unqualified satisfaction with anything purchased from me. 


\section{0 of the World's Finest Varieties for Discriminating Buyers Who Want the Best}

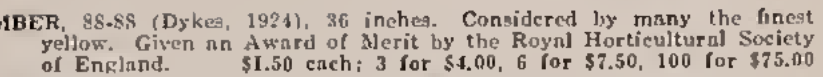

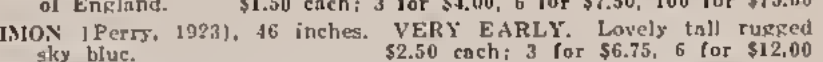

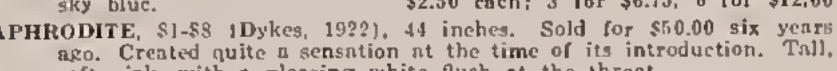

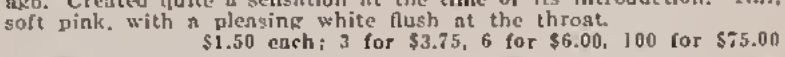

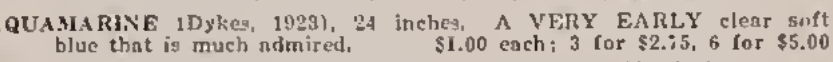

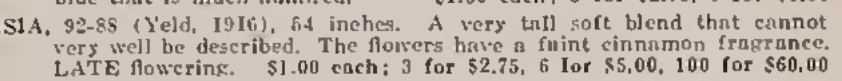

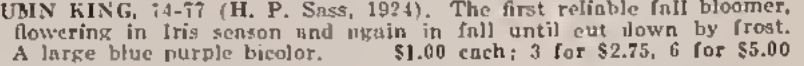

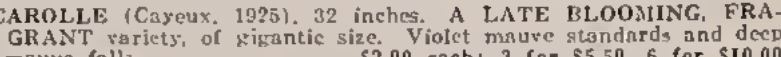

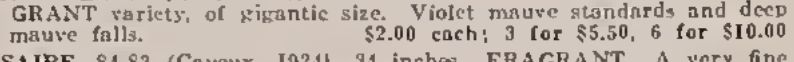

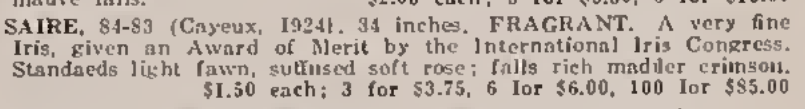

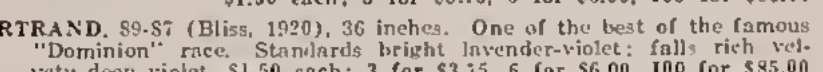

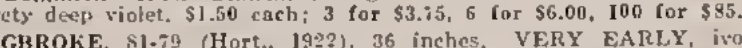

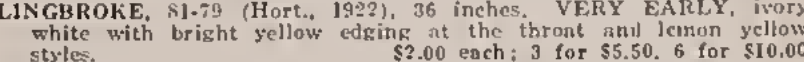

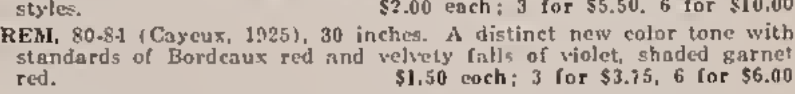

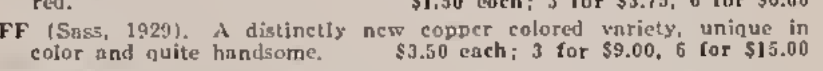

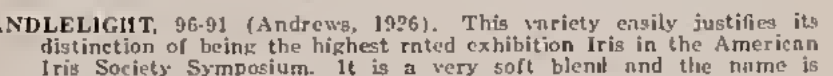

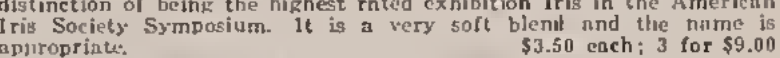

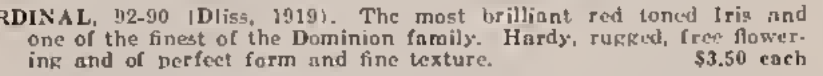

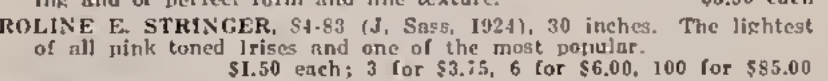

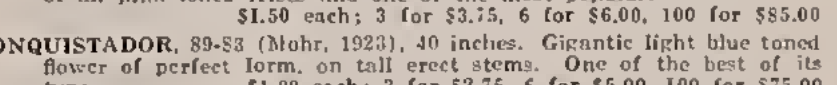
بype.

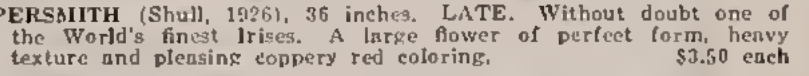

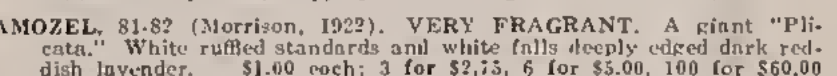
dish lavender.

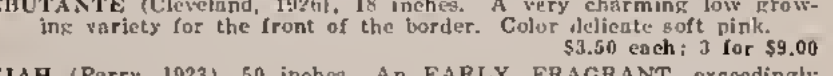

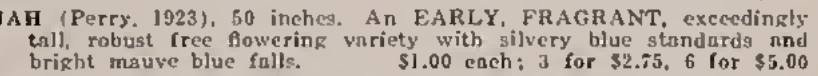

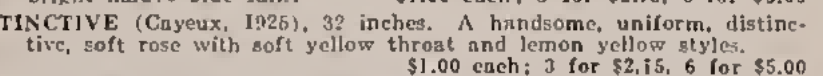

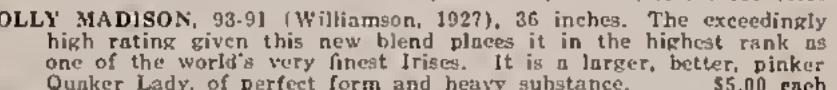

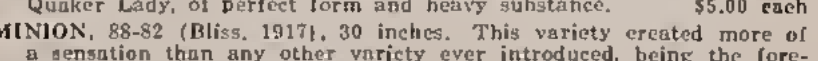

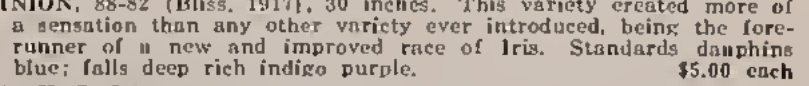

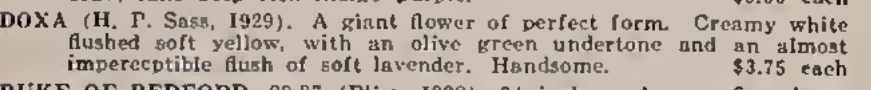

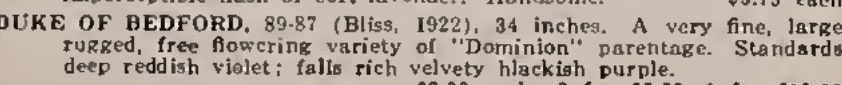

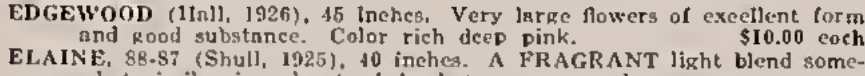

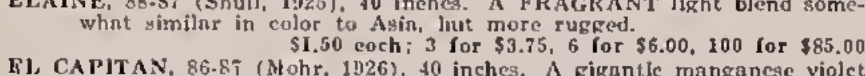

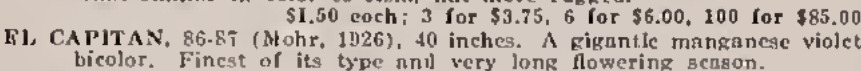

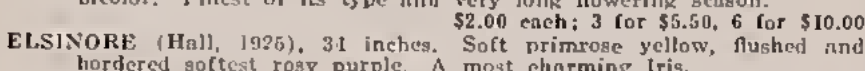

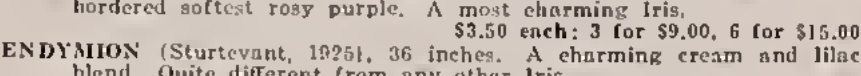
FIREFALL, (Essiz, 1105) \$1.50 ench: 3 for $\$ 3.75$. 6 for $\$ 6.00$, 100 for $\$ 85.00$

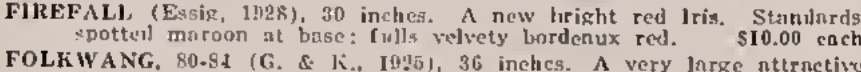

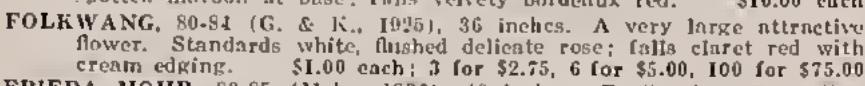

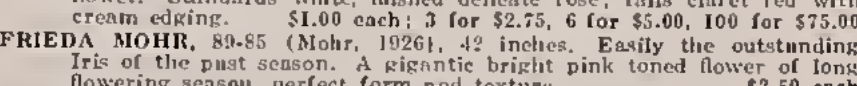

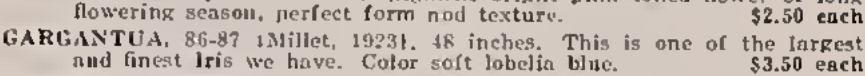

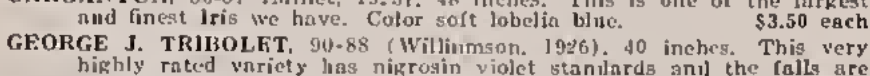

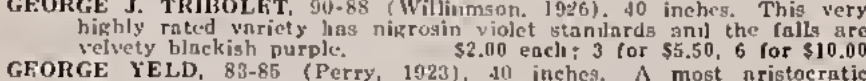

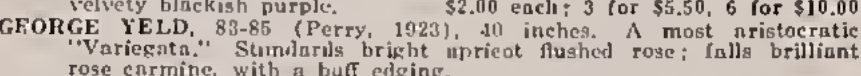

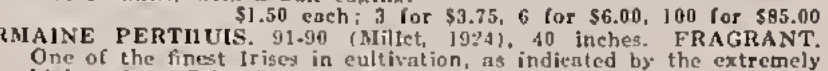

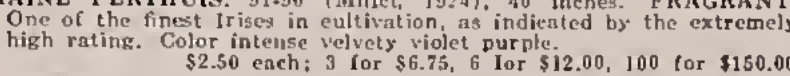

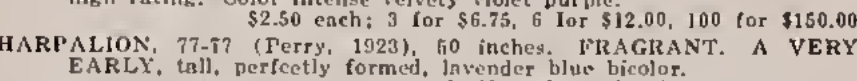

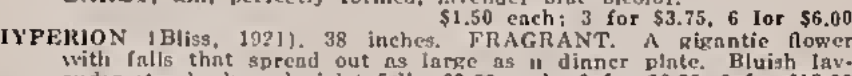

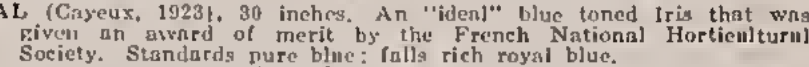

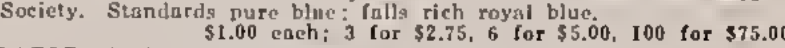

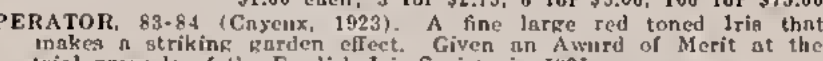

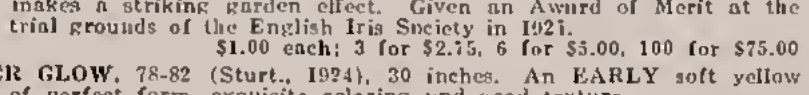

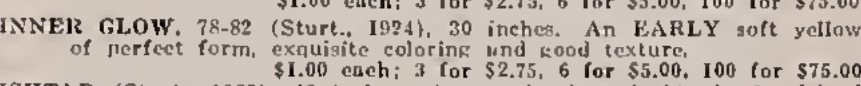

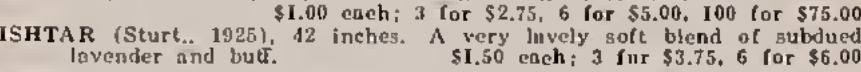

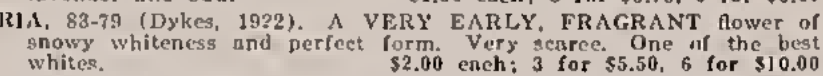

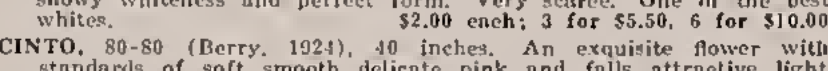

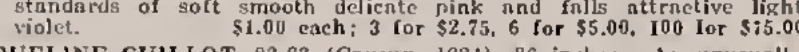

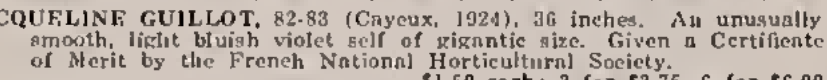

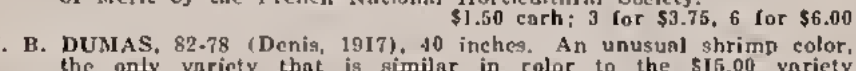

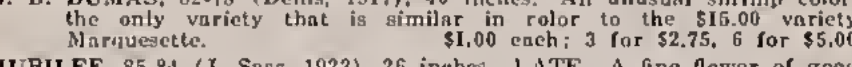

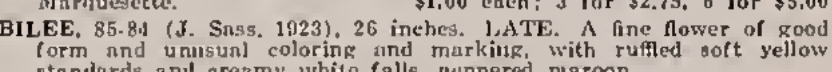

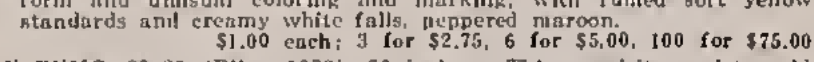

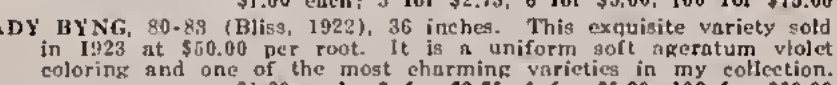

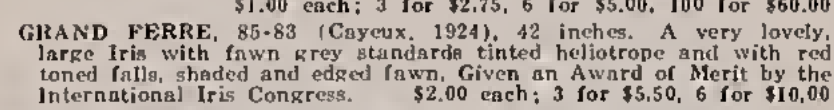

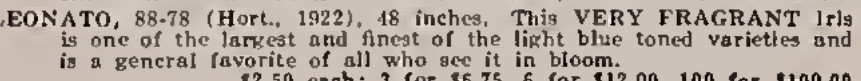

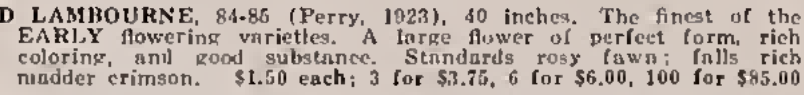

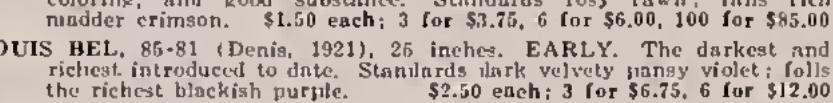

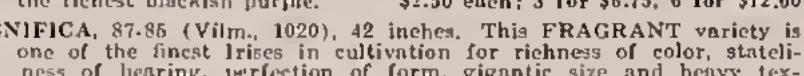
ture. It is $n$ brillitint erimson tuned hicolor.

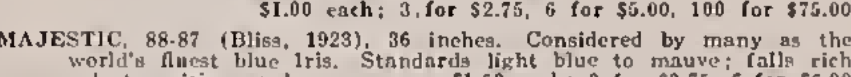

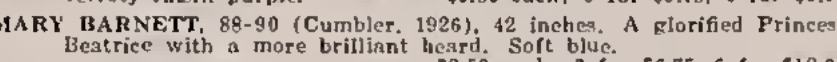
ench; 3 for 56.75 .6 for $\$ 12.00$

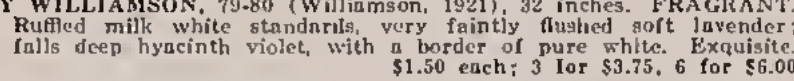

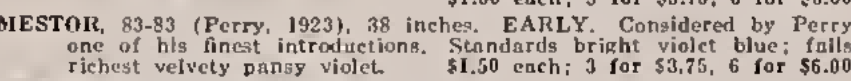

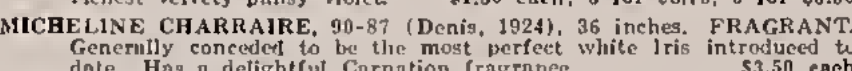

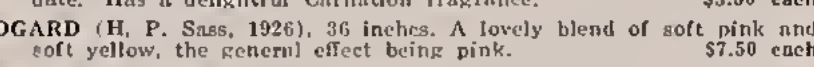

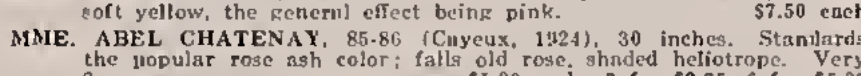

MME. DURRAND, 92-89 (Denis, 1912) 46 inches. Large ruffed glistening

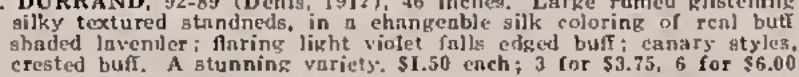

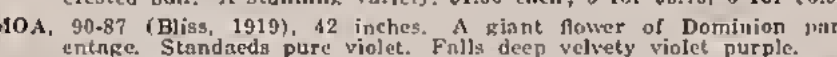

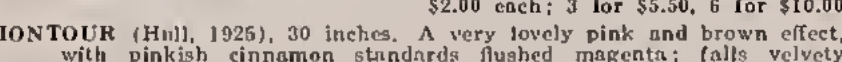

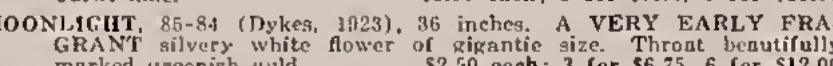

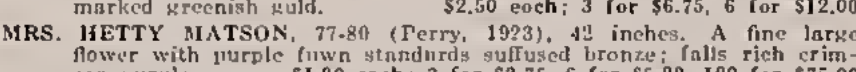

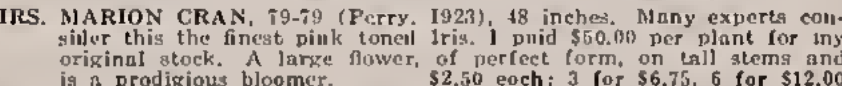

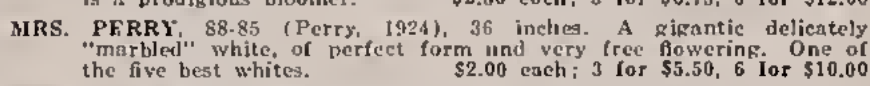
ODETTE OLIVET (Nonin, 1922), 32 inchics. An EARLY very lovely soft
nrchiid pink toned wariety. Scems to be unknown in this country.

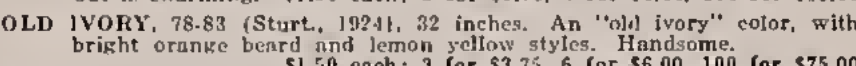

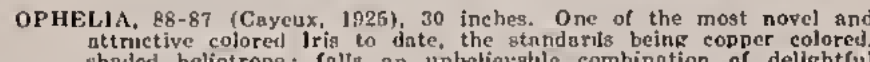

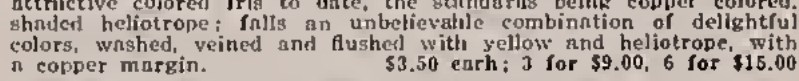

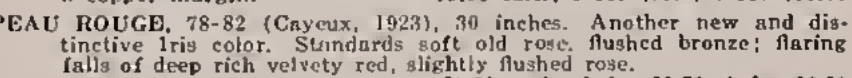

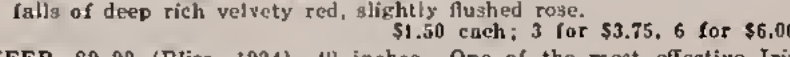

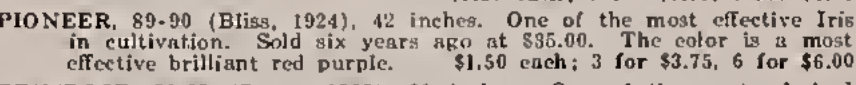

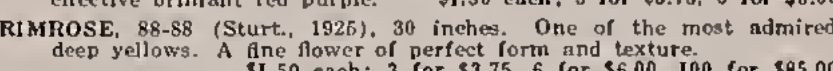

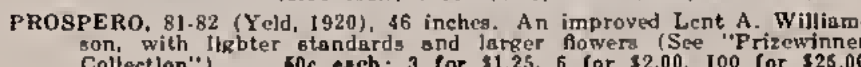

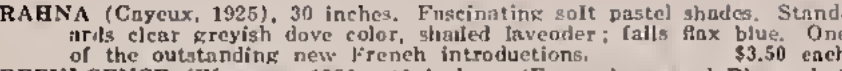

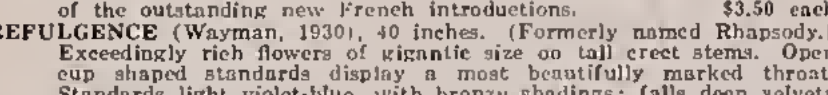

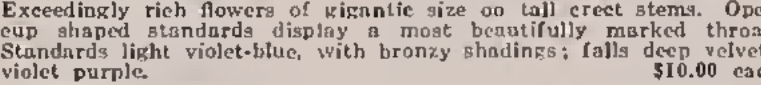

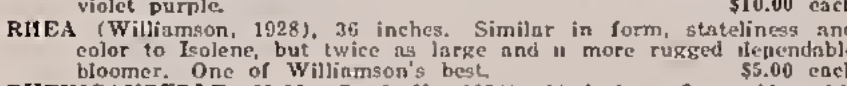

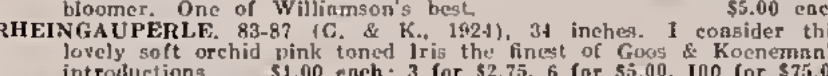

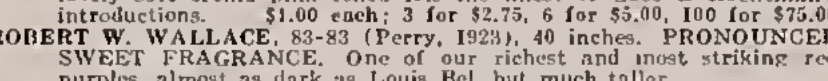

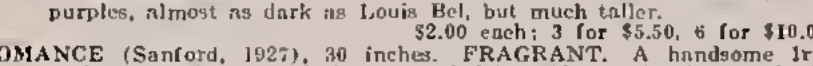

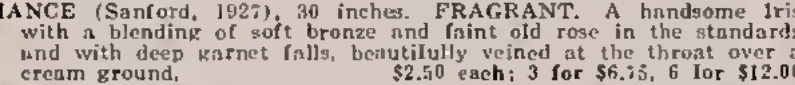

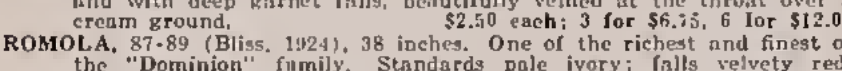

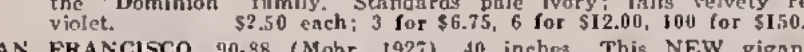

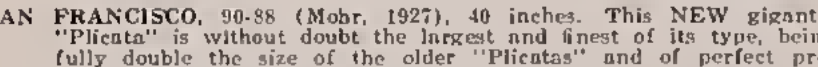

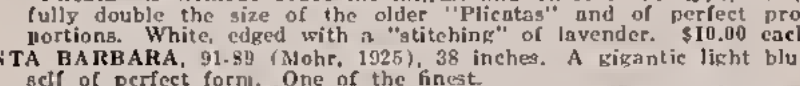

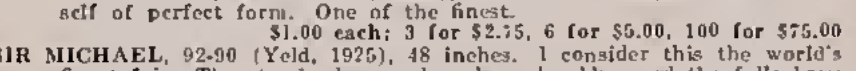

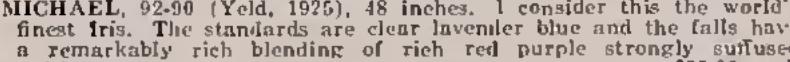

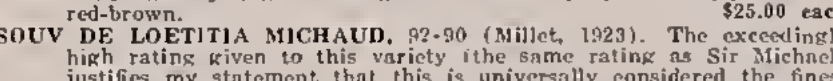

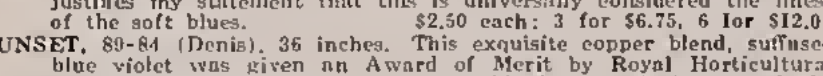

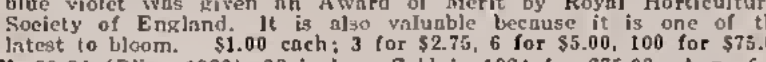

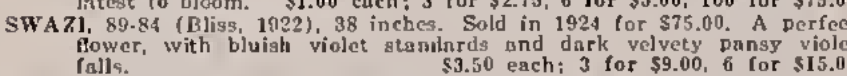

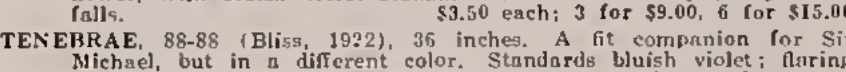

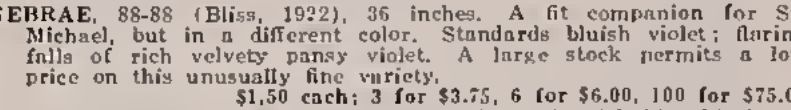

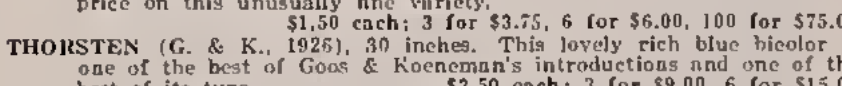

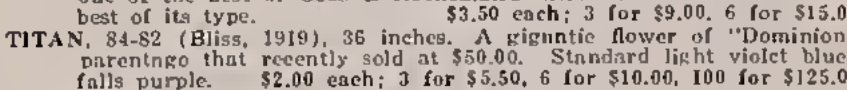

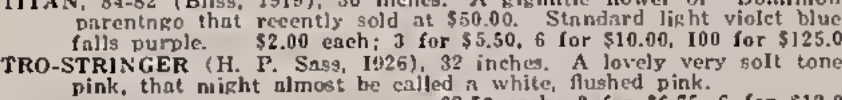

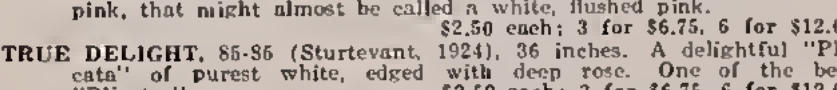

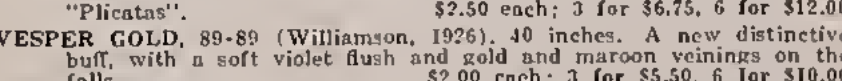
WEDGEWOOD. 87. 87 (Dykes, 1993), 12 inches, The richest "Wedsewrod

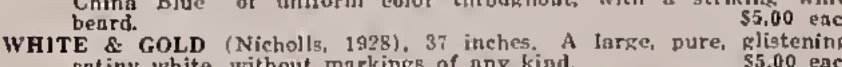

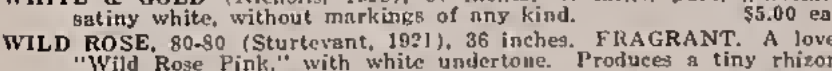

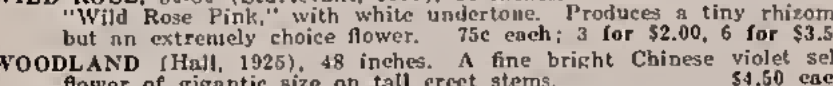

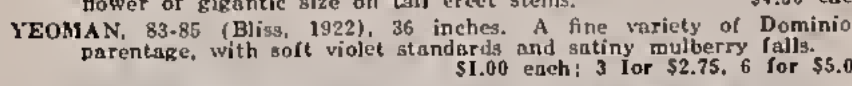

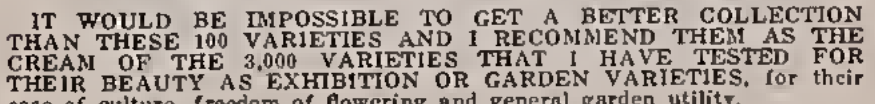




\section{Prizewinner Collection}

This PRIZEWINNER COLLECTION is the ultimate in value for the nimey expended. It contains many varieties that recently sold at $\$ 35.00$,
$\$ 50.00$ and $\$ 75.00$ for a single plant and the entire collection would have cost $\$ 250.00$ a few years ago. To-day the twenty-two prize beauties deseribed in the following pages, costing over $\$ 20.00$ if purchased separately.

The varieties chosen for this "PRIZEWINNER COLLECTION" hav been selected because they embrace the greatest possible range of color,

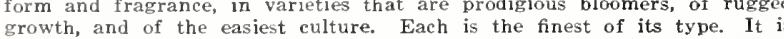
the sort of a collection that every one raves about. Your friends will tell blends in the Iris or such girantic blossoms, or such exouisite frapr They are as handsome as the choicest orchids, yet as hardy as an oak, for the hybridizer's skill has produced miracles in the Iris family durin thers with the most delightful silky texture and still athers seem to be made of the finest porcelain.

Because this PRIZEWINNER COLLECTION is made up with the greatest care, after much planning and thoughtful consideration, because business producer. The sale of a collection one year very often result in the sale of several collections the following year to friends of the first purchaser; and these in turn have other friends who wish to buy whe thought in mind, and with the expectation that it will produce an endles chain of continuous business. Nothing is allowed to go into the PRIZF upon its own merits. There are no duplicates; there are twenty-two different types of beauty to enthuse about. Read the descriptions carefully and judge for yourself: although no word picture can do them justice,

If you were to travel the world over, visiting the world's finest garden at home and abroad, spending a fortune in money and a great deal o WINNER COLLECTION, for I have grown nearly every Iris that has ever been grown, collecting them from every nook and corner of the globe, testing some three thousand varieties for their hardiness, beauty. fragrance and general garden qualities, and have selected this PRIZEWINNER Iris as a "Hobby"

BRUNO, 91-90 (Bliss, 1922), 36 inches. LATE. This is without a doub would indicate. Among three thousand varieties tested I rate it one of the five best. It is a large flower, perfectly formed, of heav of special value as a seed parent. This variety sold in 1924 at is also a root, and it is still quite scarce, but I am fortunate in having sufficient stock of it to include it in this collection and to sell it
this year at a moderate price. The standards are bronzy heliotrope and the falls are rich velvety

ORNING SPLENDOUR, 91-91 (Shull, 1923), 36 inches. FRAGRANT. LATE. This variety is generally recognized as the finest American
Iris introduced to date, as the exceedingly high rating, as well as the various awards that it has received will indicate. It was given an Award of Merit by the American Iris Society in 1922; a Bronze the same year. The very large flowers tone and are perfectly formed, of heavy
grance and borne on tall stout erect stems.

$\$ 1.00$ each; 3 for $\$ 2.75,6$ for $\$ 5.00,100$ for $\$ 60.00$ PRINCESS BEATRICE, 90-90 (Barr, 1898), 46 inches. FRAGRANT. In dreds of varieties of Iris, only ten varieties rated 90 both as an exhibition flower and as a garden Iris. Princess Beatrice was on this collection, were three more of them. A fifth one was Sir Michael, which is still selling at $\$ 25.00$ per root. Princess Beatrice is an entraneing shade of soft lavender, with flowers of perfect
form. exceptional substance, large size and smooth satiny texture.

$\$ 1.00$ each; 3 for $\$ 2.75,6$ for $\$ 5.00,100$ for $\$ \$ 0.00$
AMBASSADEUR, 92-91 (Vilmorin, 1920), 42 inches. LATE. If you want just one Iris, buy Ambassadeur. It was voted by far the most
popular Iris in the world by the membership of the American Iris Society, receiving 111 votes against 83 for its next nearest com-
petitor and only eleven varieties receiving more than 50 votes. The decision was therefore overwhelming. It is a gigantic flower of rich coloring, perfect form, good texture, on stout erect stems.
There is a blending of colors that makes any description inadequate. Placed where the sun's rays show through it. the effect is rich ruby
red.
50c each: 3 for $\$ 1.25,6$ for $\$ 2.00,100$ for $\$ 25.00$

SOUV. DE MME. GAUDICHAU, 91-88 (Millet, 1914), 40 inches. FRAGRANT. This is the largest, darkest and by far the finest of the
dark purple Irises. Even the beard has a bluish cast, which en-
hances the beauty of the flower. The falls are of a strikingly brilliant velvety blackish purple. In addition to its other attractions,
it is also very fragrant. This variety is still quite scarce, but I am fortunate enough to have a sufficient stock to include it in this "Prizewinner" Cociety of England.

BALLERINE, $90-89$ (Vilm., 1920). 48 inches. FRAGRANT. LATE. The most popular of all of the light blue toned varieties. A giganti
flower of fine form and exquisite coloring, on four foot stems. Free flowering and very fragrant. 75 each: 3 for $\$ 2.00,6$ for $\$ 3.50,100$ for $\$ 50.00$

DR. CHAS. H. MAYO (Fryer, 1924). 40 inches. FRAGRANT. This is undoubtedly the Masterpiece of the introducer. I consider it the finest
pink toned Iris introduced to date. In form it resembles Mrs. Marion Cran, but is larger; in color it resembles Susan Bliss, but is softer it has the white throat of Aphrodite, but is more massive and yet more artistic. It therefore has the combined attraction of three
famous pink toned varieties. It is also exquisitely fragrant, very famous pink toned varieties. It is also exquisitely fragrant, very constitution. It surely leaves nothing to be desired.
$\$ 1.50$ each; 3 for $\$ 3.75,6$ for $\$ 6.00,100$ for $\$ 85.00$

TRUE CHARM, 88-84 (Sturtevant, 1920), 38 inches. FRAGRANT. In my opinion this and True Delight are the two mrst satisfactory only of large size, perfect form, wonderful texture and exquisite coloring, but exceedingly rugged and free flowering. The white
standards of True Charm are delicately suffused with a soft flush
of lavender and the creamy white falls are edged with a "stitching" of the same color. $\$ 1.00$ each; 3 for $\$ 2.75,6$ for $\$ 5.00,100$ for $\$ 75.00$

GOLD IMPERIAL, 86-87 (Sturt., 1924), 33 inches. This is one of the finest deep yellows. In $1928 \mathrm{I}$ sold it at $\$ 8.00$ a plant. It is a deep, ceedingly brilliant orange beard. It has been one of the most admired Iris in my garden on account of its perfect form, unusually $\$ 1.00$ each; 3 for $\$ 2.75,6$ for $\$ 5.00,100$ for $\$ 60.00$

MILDRED PRESBY, 86-87 (Farr, 1923), 30 inches. LATE. This is one of the finest of the "A moena" type, or white bicolors so far intro-
duced. The standards are creamy white and the falls are rich dark

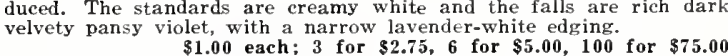

MARY GIBSON, 84-85 (Perry, 1922), 42 inches. EARLY. This is a great favorite of mine. It is a handsome, soft, rosy bronze blend, with a
yellow throat and rich golden beard, on tall, erect stems. It is different in color from any other Iris and is one of our very best
soft blends.
$\$ 1.00$ each; 3 for $\$ 2.75,6$ for $\$ 5.00,100$ for $\$ 60.00$

SUSAN BLISS, 85-86 (Bliss, 1922). 40 inches. Six years ago you could not have bought one plant of this one variety alone for the price sensation, and it has proven worthy of all the notoriety it has attained, for it is a most exquisite Iris. The orchid pink toned
flowers are of perfect form and bloom profusely on stout erect stems.
75c each; 3 for $\$ 2.00,6$ for $\$ 3.50,100$ for $\$ 50.00$

LEVERRIER, 86-82 (Denis, 1917), 52 inches. This is one of the tallest and most striking Irises in my entire collection. The flowers are very large, seven inches long by actual measurement. They are of
fine form and well placed upon very tall, erect, branching stems. pansy violet with many flowers on a stem. Its brilliant coloring stands out at a great distance and it is wanted by everybody who
sees it in bloom. I consider this one of the world's best Irises.
APACHE. 85-87 (Farr, 1926), 22 inches. A new and distinctive color Iris, the standards being a bright coppery red and the falls a dark
crimson brown. Should be in every high-class collection. There ar yery few Irises that attract as much attention in the garden, and in the front of the border for close inspection.
$\$ 1.00$ each: 3 for $\$ 2.75,6$ for $\$ 5.00,100$ for $\$ 75.00$ LONA, 84-83 (J. Sass, 1923), 30 inches. LATE. An exquisite flower a exotic in appearance as the finest orchid. In fact, it resembles Ruffled peach colored standards; white falls beautifully veined and minutely peppered violet. A real $\underset{\$ 1.50}{\mathrm{gem}}$ each : 3 for $\$ 3.75,6$ for $\$ 6.00$

CANOPUS, $84-83$ (Bliss, 1921), 36 inches. This is one of the famous Dominion race. Canopus sold recently for $\$ 25.00$ a root, but is now
sufficiently plentiful to sell at a nominal price. It is a velvety purple blend of large size, fine form and good texture.
$\$ 1.00$ each: 3 for $\$ 2.75,6$ for $\$ 5.00,100$ for $\$ 75.00$ SHEKINAH, 84-84 (Sturt., 1918). 36 inches. FRAGRANT. A very hand some clear soft yellow, with a little deeper color at the throat and
a handsome golden beard that adds to its effectiveness. It is exguisitely fragrant. The standards are slightly rutfled and the piower
is of fine form. A clump makes a most attractive garden picture. If you want just one soft yellow, buy Shekinah. SEMINOLE, 83-83 (Farr, 1920), 30 inches. LATE. This is, in my judgment, the masterpiece of the late B. H. Farr, for there is as ye
no other Iris that equals it in brilliance of color. It is a rich velvety crimson bicolor, different in color and form from Opera. For best results, place it in front of the border, with Seminole on
one side of White Knight or White Queen and Opera on the other.

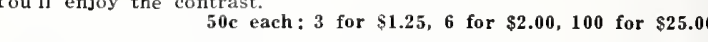

TAJ MAHAL. 82-81 (Sturt., 1921), 36 inches. A very fine pure white flower of fine form. heavy waxy substance and rugged constitution.
One of our best whites and very free flowering.
$\$ 1.50$ each; 3 for $\$ 3.75,6$ for $\$ 6.00$ FLAMMENSCHWERT, 80-80 (Goos \& Koenemann, 1920). LATE. One of the most popular and most brilliant of the yellow bicolors or "variefalls are bright velvety erimson maroon. edged orange yellow.
$\$ 1.00$ each; 3 for $\$ 2.75$, 6 for $\$ 5.00,100$ for $\$ 75.00$ OPERA, $82-83$ (Vilm., 1916), 24 inches. This is one of the ricbest violet-
red toned bicolors. It is quite deservedly one of our most popula varieties. Even the beard is of a distinctly reddish tone. The fall are just like a piece of velvet. This variety, like many of the very
finest sorts, produces small rhizomes. but blooms profusely.
50c each; 3 for $\$ 1.25,6$ for $\$ 2.00,100$ for $\$ 25.00$ WHITE KNICHT, 79-80 tiful snow white flowers of waxy texture, with delicate throat
markings. A sweetly scented flower of the finest form. $50 \mathrm{c}$ each; 3 for $\$ 1.25,6$ for $\$ 2.00,100$ for $\$ 25.00$
marking. A The individual prices on the foregoing varieties are low. It is a magnificent collection, and for the entire collection I am making a price tha
is within the reach of everybody.

I will furnish one each of the 22 Prize Winners

(value $\$ 20.75$ ) for

.$\$ 13.50$

Three each, or a total of 66 plants, for. $\$ 32.00$

Six each, 132 plants, enough for a nice clump

of each.

.$\$ 60.00$

All will be carefully labeled.

This is a most unusual offering for such high class varieties. Think of
being able to buy such wonderful varieties as Bruno, Susan Bliss, Morning

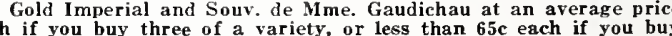
one of each. July, August and September are recommended as the best months to
set out this collection, although all bearded Iris may be transplanted a
any time when the ground is not frozen. Full instructions accompany al 


\section{Friendship Collection}

\section{NAMED VARIETIES, ALI, LABELED, WORTH \$11.25, FOR $\$ 6.50$.}

I have added to the "FRIENDSHIP COLLECTION" this ear many fine varieties that were in the Prizewinner Collection last year, thereby greatly improving the quality of the FRIENDSHIP COLLECTION. In fact it is now nearly as good as the Prizewinner Collection, but is lower in price principally because the varieties included are now sufficiently plentiful to make a more moderate price on them. They are all quite rugged and hardy and will bloom profusely any where. Like the Prizewinner Collection, there are no two alike in the FRIENDSHIP COLLECTION. It covers a fine color range and each variety is a real gem. The two collec tions together make a most comprehensive Iris garden, as the varieties in the PRIZEWINNER and FRIENDSHIP collec tions are entirely different and are selected with the thought of their being planted together where desired.

I have named this the FRIENDSHIP COLLECTION be cause I believe every person ordering it on my recommendation will become a friend and will tell others about the beautiful assortment of choice Iris they were able to buy at such a nominal price.

AFTERGLOW, $83-82$ (Sturt., 1917), 38 inches. A very lovely soft hlend that is just as diffcult to describe as the evening sky at sunset. 50 c each: 3 for $\$ 1.25,6$ for $\$ 2.00,100$ for $\$ 25.00$ ALAR. 86-87 (Vilm., 1910), 42 inches. FRAGRANT. The Cornell
Test Gardens rate this as one of the best ten. It is a gigantic flower symmetrical in form, stately in its bearing, beautiful in colorin and delightfully fragrant Standards soft violet to orcbid and of glistening silky texture. Falls rich velvety crimson-purple, with a
white throat beavily veined bronze. Bright orange beard and amber style arms.

ISOLINE.

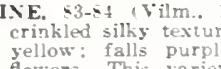

yellow: falls purp

is constanty ware and exceedingly beautiful

Shown. Given an Award of Merit by the French Royal Horticultural
Society.
50c each; 3 for $\$ 1.25,6$ for $\$ 2.00,100$ for $\$ 25.00$

LA NEIGE. To-is (Verdier, 1912), 2 inches. A very beautiful creamy white Iris of unusal
remain in good condition for a long time. It is a prodigious bloomer.
$50 \mathrm{c}$ each; 3 for $\$ 1.25$. 6 for $\$ 2.00,100$ for $\$ 23.00$

LENT A. WILllaMsox, $85-58$ (Wmsn., 1918), t2 inches. This variety Was in 1922 rated by the Anerican lris suciery as the World
Best Jris. The standards are of soft campanula violet and the fall are velvety pansy violet. There is a blending of sellow at the throa:
and a rich golden beard. The form is perfect and the petals are of is one of our very tinest garden Irises
$50 \mathrm{c}$ each: 3 for $\$ 1.25,6$ for $\$ 2.00,100$ for $\$ 23.00$ LORD OF JTXE, s8-8 (Yeld, 1911), to inches. FR.AGRANT. Flowers of gigantic size, measuring seven inches in length in nys garden. De
ightful cinnamon fragrance. Standards soft lavender blue: fall
rich violet blue. 50c each: 3 for $\$ 1.25$, 6 for $\$ 2.00,100$ for $\$ 25.00$
50.

MME. CHOBALT, s1-s0 (Denis, 1916), 3n inches. LATE. A most unusual Iris, that must be sen to be appreiated. No deciription can do 1
justice. Groundwork soft pleasing yellow, the silky ruffed standard justice. Groundwork soft pleasing yellow, the silky ruffed standards
being beautifully fushed rosy bronze, while the falls are edged with a
"stitching" of Prussian red, the throat consperuously veined the same coloring. Bronze styles and rich orange beard. $\$ 2.00,100$ for $\$ 25.00$
$50 \mathrm{c}$ each; 3 for $\$ 1.25,6$ for $\$ 2.06$

MOTHER OF PEARL, \&s (Sturt., 1917), 4s inches. LATE. This is a very large, perfectly shaped Alower of exceptional substance and
iridescent Mother of Pearl colorings, having a white throat overiridescent Mother of Pearl colorings, having a white throat over-
laid with gold. The flowers a re nicely placed on well-hranched $\$$ tems.
J0c each; 3 for $\$ 1.25,6$ for $\$ 2.00$. 100 for $\$ 25.00$

ONORIS, 74-i isturt., 1920), 35 inches. A very lovely "Yellow Plicata,"
I have never had enough stock to feel justified in listing it until this year. Ground color soft vellow edged and dusted with maroot
and lavender.

PRINCE LOHENGRIN, $33-81$ (Mohr, 1924), 40 inches. EARLY. This very lovely pink toned variety has been greatly admired by all who
have seen it in bloom in my garden A greatly improved Lohengrin
being larger and taller.
ijo each : 3 for $\$ 2.00$. 6 for $\$ 3.30$

PROSPER LALGIER, $85-8$ ( finest of the hronze tories. Standards iridescent fiery bronze: fall
ricb velvety ruhy red. The throat is white with an intricate networh $\$ 2.00,100$ for $\$ 25.00$

TROOST, $78-79$ (Denis, 190:), 34 inches. This is a most unusual Iris on
account of the lacy effect given to the falls by being completely ove heing about twice as lange. The general color is 8 striped pink.
$30 \mathrm{c}$ each; 3 for $\$ 1.25$. 6 for $\$ 2.00$, 100 for $\$ 25.00$

ZOCAVE, $35 .-56$ (Vilm. 1922), 30 inches. LATE. An unusual plicata of

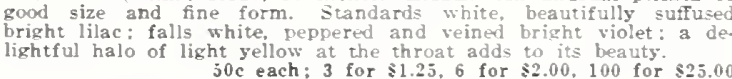

\section{FRIENDSHIP COLLECTION}

I will furnish one each of the foregoing 20 choice varieties (value $\$ 11.00$ ) all properly labeled, for.

$\$ 6.50$

Three of each (a total of 60 plants) for.... $\$ 16.50$ Six of each (enough for a fine landscape or gar.

den clump), a total of 120 plants. for. . . . $\$ 2 \$ .00$
Japanese Iris

There is nothing more show than the Japanese Iris and they bloom after the others have finished fowering, thus prolonging the flowering season. Some of them are nearly as large as a dinner plate; there are singles and doubles, selfs, mottled and striped effects; soft pastel shades and the most brilliant colorings. I have been collecting them from man sources for the past 20 years and now offer the following collection.

25 Plants in 5 varieties, mixed, my selection, unlabeled $\$ 9.75$ 50 Plants in 10 varieties, mixed. my selection, unlabeled $\$ 15.50$ 25 Plants in 5 varieties, labeled, $m$ s selection, for, ... $\$ 14.50$

50 Plants in 10 varieties, labeled, my selection, for.... .\$27.50

1 each of 50 varieties, my master list, all properly

labeled. for

\section{Japanese Iris Seedlings}

These are all blooming size plants and are seedlings only in the sense that they are grown from seeds instead of from root divisions. Japanese Iris grown from seed show great variation from the parent and among these seed grown plant you are likely to find some novel forms, markings and color the finest varieties only are used.

50 Japanese seedlingr. my selection. 25 Japanese seedlings, my selection, without labels... $\$ \mathbf{i} .0$

\section{Siberian Iris}

Many eminent authorities consider these the finest of all Irises. They are rugged and hardy and easy to grow in an soil or location, in full sun or semi-shade; and are excellen them and offer the following special collections:

50 named siberian lris. my selection. in about 5 varie.

ties, unlabeled, for

100 named Siberian Iris, my selection, in about 10 varie-

ties, unlabeled, for.

6 each of 4 choice varieties, my selection, all properly

labeled, total 24 plants, for.

$\$ 6.00$

6 each of 10 choice varieties, my selection, all properly

labeled, total 60 plants, for.

\section{Siberian Iris Seedlings}

For a garden full of fine Siberian Iris at a nominal cost this is your chance. These seedlings are grown from only the finest stock. They are fowrering size plants and are seedlings only in the sense that they are grown from seeds and althou Siberian Iris come only in whites and in various shades of blues and purples.

50 Siberian seedlings in assorted colors, unlabeled, for $\$ 7.50$ 100 Siberian seedlings in assorted colors, unlabeled, for $\$ 10.00$
ETE, $8-89$ (G. \&. K., 1925). 38 imches. A fine large flowered dark
lavender self. Very free flowering. A rugged hardy landscap

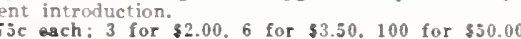




\section{Rainbow Collection}

\section{RAINBOW COLLECTION OF BEARDED IRIS}

$\$ 25.00$ worth of Iris for $\$ 6.75$

For those who wish a garden full of fine flowers, in all the colors of the rainbow, at a nominal cost, without the care of keeping the varieties separate, this is a real opportunity and a great bargain. The labor saved in putting up this RAINBOW COLLECTION without labels enables me to furnish the utmost in value at the minimum cost. My space is limited and there are always certain plantings that must be moved in order to make room for the propagation of new varieties. My necessity is your good fortune. I cannot tell in advance what varieties are likely to go into these RAINBOW COLLECTIONS, but as I have nothing but very choice varieties, you are sure to be pleased. I guarantee that every one of these collections would cost $\$ 25.00$ or more if bought at regular catalogue prices; some would cost $\$ 50.00$ or more, as it often happens that many very high priced varieties are included. Each collection will contain a liberal assortment of colors and I guarantee that each collection will contain such famous varieties as Ambassadeur, Lent A. Williamson, Lord of June, Mother of Pearl, etc.

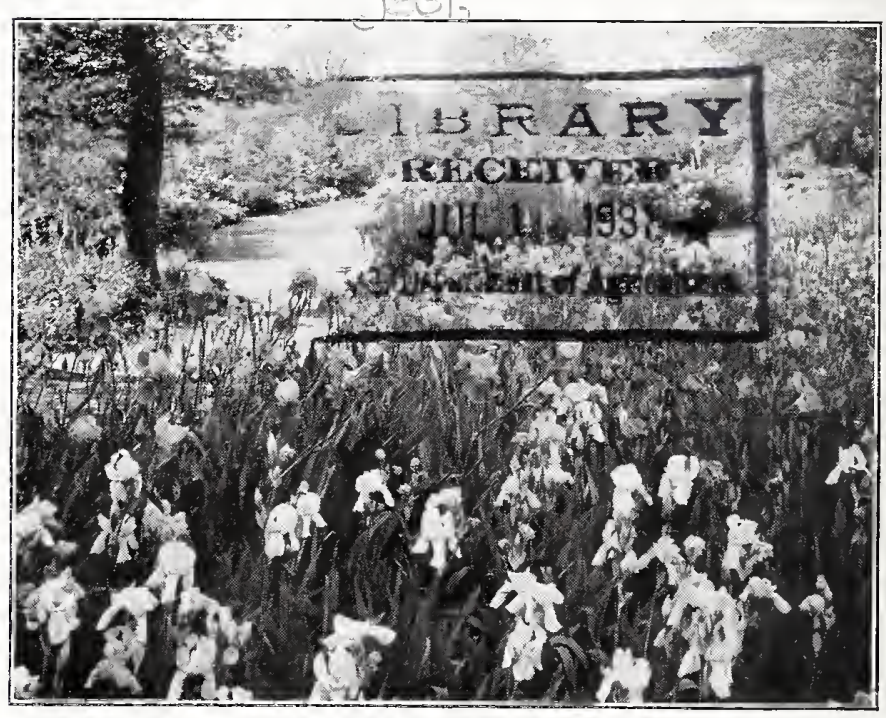

RAINBOW COLLECTION-50 CHOICE BEARDED IRIS, MY SELECTION, WITHOUT LABELS, FOR . . .\$6.75

100 PLANTS, CHOICE ASSORTMENT, UNLABELED $\$ 12.00$

Full planting instructions accompany all shipments.

\section{$40+100$ \\ ROBERT WAYMAN}

3909-214TH PLACE

BAYSIDE

LONG ISLAND, N. Y. 